\title{
Survey of Difference of Conflict Resolution Styles and Behavioral Problems of Girls In Employed Mothers with Housekeeper Mothers
}

\author{
Mehdi Akbarian ${ }^{1}$, Zohreh Mazinani ${ }^{2}$ \\ ${ }^{1}$ Masters of social welfare, Arvin Institute of Development of Survey Studies \\ ${ }^{2}$ Researcher , Arvin Institute of Development of Survey Studies \\ mehdi.akbarian84@gmail.com
}

\begin{abstract}
The purpose of this research was to compare styles of conflict resolution and behavioral problems of girls in employed and housekeeper mothers. In this research that was done using casual-comparison method (after events) 200 employed mothers and 200 housekeeper ones of girls of high schools in shiraz (Iran)were selected as the sample based on cluster-random method. Rahim Organizational Conflict Inventory-II (ROC-II) and children's behavioral problem questionnaire (parental form, 1994) were used for information collection that was previously normalized in studies conducted in Iran and its validity has been confirmed. In this research, reliability of the questionnaire was assessed through Cronbach alpha and was confirmed with a high reliability of 0.80 . The t-test was used to test the hypotheses. The results showed that there is a statistically significant difference between employed and housekeeper women in all styles except conflict resolution style. And integration conflict resolution style and avoiding conflict resolution style in employed women are more than those in housekeeper ones and also, required conflict resolution style in housekeeper women is more than that in employed ones. Also, the results showed that there is a statistically significant difference between girls of employed and housekeeper women in hyperactivity and aggression, anxiety and depression, disorder, and lack of attention. This research confirms that employment of women results in enhancement of behavioral disorder among children. It is suggested that policy makers and planners in the country must pay attention to this point.
\end{abstract}

Keywords: Conflict resolution styles, Behavioral disorders, Mothers, Employment

\section{INTRODUCTION}

Family is the first location of social communication for a child and essentially, a child knows the expectations of his/her own social life in the framework of family environment in terms of the type of his/her parental educative methods. So, education and training of the child and the formation of child growth dimensions that are reflected in occurrence of the child behaviors undoubtedly will be affected by parents. Studies have shown that behavioral problems are of the most common problem that children and adolescents associated with it (Halahan and Kafman, 2008). On the other hand, if some problems such as lack of attention, hyperactivity, behavioral disorder, comprehensive anxiety, depression, disobedience, fear, and etc that can be occurred in the form of beating, fight, yelling and screaming, sabotage, threat, escape from school, educational failure, and delinquency are not be paid attention, can result in behavioral problems (Halahan and Kafman, 2008). The studies have shown that behaviors such as seclusion and physical complaints are also behavioral disorders that 
after the second year of the school have gradually increased and it reaches considerable and worrying level in fifth and sixth years. Indeed, when a child achieves cognitive ability he/she will be able to remember and predict negative and stressful events and imagine them (Fanti, 2007). Many factors such as parenting (Farzadfar and Hooman, 2007), anxiety and mother depression (Mohammadzadeh and Najafi, 2010), exciting atmosphere and matrimony satisfaction (Soltanifar and Bina, 2007), factors related to school and attitude of teachers (Fortin et al., 2010), understood family relations by children, mutual and dynamic interactions among persons, multiple levels of environment and supportive relations of family members (Lubenko and Sebre, 2010) are effective on creating children behavioral problems. Also, according to determined studies, each of children behavioral problems can underlie the other problems and occur in various forms in adulthood. On the other hand, there is the possibility of occurrence of conflict in every ones' life. That how people react at time of the occurrence of conflict and what approaches they select to resolve the conflict are important. Conflict is inevitable part of human being. Both in personal life and in social life, there is a possibility of occurrence of conflict whenever and wherever people are social (Babapour, 2006). The conflict resolution methods are behaviors that the person shows them facing with a conflict situation to can overcome that situation (Dibaji Foroushani et al., 2008). Studies have shown that the way of parental communication with children is the strongest factor affecting family interaction patterns, especially during periods of children life that essential changes of mental growth are gone and since mother is the first person that a baby communicates with her, therefore, she plays the most important role in educating mental and emotional properties of baby and is considered as health or illness center (Godarzi et al., 2010). Today, women employment especially in Shiraz (Iran) has had a growing trend so that many women spend less time at home. Nevertheless, despite importance of job and family, limited studies have been conducted in the form of attention to interactions between job and family (Godarzi et al., 2010). This research aims to compare conflict resolution styles and behavioral problems in employed and housekeeper mothers and answers these questions that can employment of women due to restricted presence at home effective on children behavioral problems? And has employment resulted in difference in women conflict resolution styles?

\section{METHOD}

The present study is of a comparative-casual or after event type. Statistical population in this research was the mothers of high school girls in shiraz (Iran) . 200 employed mothers and 200 housekeeper ones in shiraz (iran)were selected using cluster-random method. The most important data collection tool in this research was Rahim Organizational Conflict Inventory-II (ROC-II) and children's behavioral problem questionnaire (parental form, 1994).

\section{Rahim Organizational Conflict Inventory-II (ROC-II)}

Rahim Organizational Conflict Inventory-II (ROC-II) is a questionnaire with 28 questions that was created by Rahim et al. (2004) for the first time and it was normalized by Haghighi et al. (2012) for first time. Sine this questionnaire is standard, there is no need to investigate its validity again in this research and only its reliability was calculated using Cronbach alpha after completion of 30 questionnaires by research samples. The reliability for integration conflict resolution, required conflict resolution, the dominant conflict resolution, avoiding conflict resolution, and reconciliation conflict resolution was obtained $0.82,0.84,0.81,0.80$, and 0.82 , respectively indicating acceptable reliability of the questionnaire. 
American Research Journal of Humanities and Social Science (ARJHSS)

\section{Children's behavioral problem questionnaire (parental form, 1994)}

This questionnaire includes 31 items and issues related to health and children habits. Scoring in this questionnaire is in a three-scale form including: ture $=0$; partly true $=1$; and completely true $=2$. Rother (1994) did a wide study about 10- and 11-year old children. In this study, 1536 children were investigated using Rother's questionnaire and also the relaibility of this questionnaire was assessed. Rother reported reliability of retest and questionnaire 0.74 in a pretest-posttest study within two months. In Iran also reported reliability of correlation parental form 0.74 in a pretest-posttest study within two months.(quoted by Bardideh et al., 2010). Sine this questionnaire is standard, there is no need to investigate its validity again in this research and only its reliability was calculated using Cronbach alpha after completion of 30 questionnaires by research samples. The reliability for hyperactivity and aggression, anxiety and depression, social incompatibility, anti-social behaviors, and attention deficit disorder was obtained $0.83,0.86,0.80,0.84$, and 0.82 , respectively indicating an acceptable reliability of the research questionnaire. Also, SPSS software and t-test were used to analyze data and to test hypotheses, respectively.

\section{Findings}

In this research, 200 employed mothers and 200 housekeeper ones in shiraz (iran)were studied. For employed women, the average of styles of integration conflict resolutions, required conflict resolution, the dominant conflict resolution, avoiding conflict resolution, and reconciliation conflict resolution was obtained 24.76, 20.04,19.92, 24.72, and 14.72, respectively. For housekeeper women, the average of styles of integration conflict resolutions, required conflict resolution, the dominant conflict resolution, avoiding conflict resolution, and reconciliation conflict resolution was obtained 29.92, 26.08, 16.44, 15.48, and 15.88, respectively. The average of behavioral disorder of employed women girls in hyperactivity and aggression, anxiety and depression, social incompatibility, anti-social behaviors, and attention deficit disorder was obtained 2.68, 1.87, 1.83, 1.89, and 2.20, respectively. The average of behavioral disorder of housekeeper women girls in hyperactivity and aggression, anxiety and depression, social incompatibility, anti-social behaviors, and attention deficit disorder was obtained $1.90,1.72,1.81,1.80$, and 1.80 , respectively.

Hypothesis 1: conflict resolution styles are different among employed and housekeeper mothers in Shiraz (Iran) .

This hypothesis has been tested using t-test and the results are given in Tables 1 and 2.

Table1. investigating the difference of average of integration conflict resolution styles between employed and housekeeper women

\begin{tabular}{|c|c|c|c|c|c|c|c|c|c|}
\hline \multicolumn{6}{|c|}{ t-test of equality of averages } & \multicolumn{2}{|c|}{$\begin{array}{l}\text { Levene's test of } \\
\text { equality of variances }\end{array}$} & & \\
\hline \multicolumn{2}{|c|}{$\begin{array}{c}\text { Confidence } \\
\text { interval of } 95 \%\end{array}$} & \multirow[t]{2}{*}{$\begin{array}{c}\text { Average } \\
\text { Difference }\end{array}$} & \multirow[t]{2}{*}{$\begin{array}{c}\text { Significance } \\
\text { level }\end{array}$} & \multirow{2}{*}{$\begin{array}{l}\text { Degree } \\
\text { of } \\
\text { freedom }\end{array}$} & \multirow[t]{2}{*}{$\mathrm{t}$} & \multirow[t]{2}{*}{$\begin{array}{l}\text { Significa } \\
\text {-nce level }\end{array}$} & \multirow[t]{2}{*}{$\mathrm{F}$} & & \\
\hline $\begin{array}{l}\text { Upper } \\
\text { limit }\end{array}$ & $\begin{array}{l}\text { Lower } \\
\text { limit }\end{array}$ & & & & & & & & \\
\hline-3.425 & -6.895 & -5.16 & 0.000 & 198 & 5.902 & \multirow[t]{2}{*}{0.002} & \multirow[t]{2}{*}{6.134} & $\begin{array}{l}\text { Variances } \\
\text { are equal }\end{array}$ & \multirow[t]{2}{*}{ Integration } \\
\hline-3.425 & -6.895 & -5.16 & 0.000 & 178.50 & 5.902 & & & $\begin{array}{c}\text { Variances } \\
\text { aren't equal }\end{array}$ & \\
\hline
\end{tabular}

Volume 2 
American Research Journal of Humanities and Social Science (ARJHSS)

\begin{tabular}{|c|c|c|c|c|c|c|c|c|c|}
\hline 1.892 & 0.932 & 3.48 & 0.001 & 198 & 0.675 & \multirow[t]{2}{*}{0.001} & \multirow[t]{2}{*}{2.374} & $\begin{array}{l}\text { Variances } \\
\text { are equal }\end{array}$ & \multirow[t]{2}{*}{ Dominant } \\
\hline 1.892 & 0.932 & 3.48 & 0.001 & 196.247 & 0.675 & & & $\begin{array}{l}\text { Variances } \\
\text { aren't equal }\end{array}$ & \\
\hline 3.102 & -4.978 & -5.68 & 0.000 & 198 & -8.545 & \multirow[t]{2}{*}{0.001} & \multirow[t]{2}{*}{12.179} & $\begin{array}{l}\text { Variances } \\
\text { are equal }\end{array}$ & \multirow[t]{2}{*}{ Required } \\
\hline 3.102 & -4.978 & -5.68 & 0.000 & 178 & -8.545 & & & $\begin{array}{l}\text { Variances } \\
\text { aren't equal }\end{array}$ & \\
\hline 3.589 & 0.091 & 8.840 & 0.039 & 198 & 2.088 & \multirow[t]{2}{*}{0.002} & \multirow[t]{2}{*}{5.120} & $\begin{array}{l}\text { Variances } \\
\text { are equal }\end{array}$ & \multirow[t]{2}{*}{ Avoiding } \\
\hline 3.589 & 0.091 & 8.840 & 0.040 & 91.97 & 2.088 & & & $\begin{array}{l}\text { Variances } \\
\text { aren't equal }\end{array}$ & \\
\hline-1.898 & -0.502 & -1.16 & 0.091 & 198 & 3.412 & \multirow[t]{2}{*}{0.187} & \multirow[t]{2}{*}{14.247} & $\begin{array}{l}\text { Variances } \\
\text { are equal }\end{array}$ & \multirow[t]{2}{*}{$\begin{array}{c}\text { Reconcilia } \\
\text {-tion }\end{array}$} \\
\hline-1.898 & -0.502 & -1.16 & 0.091 & 171.50 & 3.412 & & & $\begin{array}{l}\text { Variances } \\
\text { aren't equal }\end{array}$ & \\
\hline
\end{tabular}

As can be seen in Table 1, the significance level of t-test in all styles except reconciliation conflict resolution is lower than 0.05 . Consequently, there is a statistically significant difference in conflict resolution styles (in integration, dominant, required, and avoiding conflict resolution styles) between employed and housekeeper women, but there is not any difference in reconciliation conflict resolution style between employed and housekeeper women.

Table2. Average and standard deviation of conflict resolution styles in employed and housekeeper women

\begin{tabular}{|c|c|c|c|c|}
\hline Standard deviation & Average & Number & & \\
\cline { 1 - 3 } 5.328 & 24.76 & 200 & Employed women & Integration \\
\hline 3.135 & 29.92 & 200 & Housekeeper women & \\
\hline 3.790 & 19.92 & 200 & Employed women & Dominant \\
\hline 3.308 & 16.44 & 200 & Housekeeper women & \\
\hline 2.892 & 20.04 & 200 & Employed women & Required \\
\hline 1.676 & 26.08 & 200 & Housekeeper women & \multirow{2}{*}{ Avoiding } \\
\hline 3.801 & 24.72 & 200 & Employed women & \\
\hline 4.939 & 15.88 & 200 & Housekeeper women & \multirow{2}{*}{ Reconciliation } \\
\hline 2.801 & 14.72 & 200 & Employed women & \\
\hline 2.939 & 15.88 & 200 & Housekeeper women & \\
\hline
\end{tabular}

As can be observed in Table 2, the average integration conflict resolution style in housekeeper women is more than that of the employed women. The dominant conflict resolution style in employed women is more than that of the housekeeper women. The average required conflict resolution style in housekeeper women is more than that of the employed women. The average avoiding conflict resolution style in employed women is more than that of the housekeeper women. But there is no difference in the average reconciliation conflict resolution style between employed and housekeeper women.

Hypothesis 2: The extent of behavioral problems is different among girls of employed and housekeeper mothers in Shiraz (Iran) .

This hypothesis has been tested using t-test and the results are given in Tables 3 and 4 . 
American Research Journal of Humanities and Social Science (ARJHSS)

Table3. investigating the difference of average of behavioral disorders in girls with employed and housekeeper women

\begin{tabular}{|c|c|c|c|c|c|c|c|c|c|}
\hline \multicolumn{6}{|c|}{ t-test of equality of averages } & \multicolumn{2}{|c|}{$\begin{array}{l}\text { Levene's test of } \\
\text { equality of variances }\end{array}$} & & \\
\hline \multicolumn{2}{|c|}{$\begin{array}{c}\text { Confidence interval } \\
\text { of } 95 \%\end{array}$} & \multirow[t]{2}{*}{$\begin{array}{c}\text { Average } \\
\text { Difference }\end{array}$} & \multirow[t]{2}{*}{$\begin{array}{c}\text { Significance } \\
\text { level }\end{array}$} & \multirow[t]{2}{*}{$\begin{array}{l}\text { Degree of } \\
\text { freedom }\end{array}$} & \multirow[t]{2}{*}{$\mathrm{t}$} & \multirow[t]{2}{*}{$\begin{array}{c}\text { Significance } \\
\text { level }\end{array}$} & \multirow[t]{2}{*}{$\mathrm{F}$} & & \\
\hline $\begin{array}{l}\text { Upper } \\
\text { limit }\end{array}$ & $\begin{array}{l}\text { Lower } \\
\text { limit }\end{array}$ & & & & & & & & \\
\hline 1.808 & 0.128 & 0.780 & 0.048 & 98 & 1.722 & \multirow[b]{2}{*}{0.020} & \multirow[b]{2}{*}{10.220} & Variances are equal & \multirow[t]{2}{*}{ Integration } \\
\hline 1.808 & 0.128 & 0.780 & 0.048 & 97.48 & 1.722 & & & $\begin{array}{c}\text { Variances aren't } \\
\text { equal }\end{array}$ & \\
\hline 1.132 & 0.708 & 0.15 & 0.000 & 98 & 4.701 & \multirow[b]{2}{*}{0.001} & \multirow[b]{2}{*}{10.917} & Variances are equal & \multirow[t]{2}{*}{ Dominant } \\
\hline 1.132 & 0.708 & 0.15 & 0.000 & 77.80 & 4.701 & & & $\begin{array}{c}\text { Variances aren't } \\
\text { equal }\end{array}$ & \\
\hline 1,125 & 0.715 & 0.05 & 0.129 & 94 & 4.701 & \multirow{2}{*}{0.121} & \multirow{2}{*}{11.801} & Variances are equal & \multirow[t]{2}{*}{ Required } \\
\hline 1.125 & 0.715 & 0.05 & 0.129 & 81.50 & 4.701 & & & $\begin{array}{l}\text { Variances aren't } \\
\text { equal }\end{array}$ & \\
\hline 1.081 & 0.814 & 0.09 & 0.128 & 92 & 2.401 & \multirow{2}{*}{0.121} & \multirow[b]{2}{*}{11.427} & Variances are equal & \multirow[t]{2}{*}{ Avoiding } \\
\hline 1.081 & 0.814 & 0.09 & 0.128 & 80.11 & 2.401 & & & $\begin{array}{c}\text { Variances aren't } \\
\text { equal }\end{array}$ & \\
\hline 1.002 & 0.808 & 0.4 & 0.000 & 95 & 4.701 & \multirow[b]{2}{*}{0.001} & \multirow[b]{2}{*}{9.823} & Variances are equal & \multirow{2}{*}{$\begin{array}{c}\text { Reconcilia } \\
\text {-tion }\end{array}$} \\
\hline 1.002 & 0.808 & 0.4 & 0.000 & 77.22 & 4.701 & & & $\begin{array}{c}\text { Variances aren't } \\
\text { equal }\end{array}$ & \\
\hline
\end{tabular}

According to Table 3, the significance of t-test in all behavioral disorders of girls except social Incompatibility and anti-social behaviors is lower than 0.05 and thus there is a statistically significance difference in behavioral disorders (hyperactivity and aggression, anxiety and depression, social incompatibility, and attention deficit disorder) of girls of employed and housekeeper mothers.

Table4. Average and standard deviation of behavioral disorders in girls in terms of employment status of the mother

\begin{tabular}{|c|c|c|c|c|}
\hline Standard deviation & Average & Number & \multicolumn{2}{|c|}{$\begin{array}{c}\text { Hyperactivity and } \\
\text { aggression }\end{array}$} \\
\hline 1.02 & 2.68 & 200 & Employed women & Anxiety and depression \\
\hline 1.01 & 1.90 & 200 & Housekeeper women & \\
\hline 1.42 & 1.87 & 200 & Employed women & \multirow{2}{*}{ Social incompatibility } \\
\hline 1.12 & 1.72 & 200 & Housekeeper women & \\
\hline 1.32 & 1.83 & 200 & Employed women & \multirow{2}{*}{ Anti-social behaviors } \\
\hline 1.20 & 1.81 & 200 & Housekeeper women & \\
\hline 1.32 & 1.89 & 200 & Employed women & \\
\hline 1.12 & 1.80 & 200 & Housekeeper women & \\
\hline 1.32 & 2.20 & 200 & Employed women & attention deficit disorder \\
\hline 1.02 & 1.80 & 200 & Housekeeper women & \\
\hline
\end{tabular}

As can be observed in Table 4, the average hyperactivity and aggression in girls with employed women is more than that of the girls with housekeeper women. The average anxiety and depression in girls with employed women is more than that of the girls with housekeeper women. The average attention deficit disorder in girls with employed women is more than that of the girls with housekeeper women. 


\section{DISCUSSION AND CONCLUSIONS}

The results of the present study showed that the average integration conflict resolution style in housekeeper women is more than that of the employed women and it seems employed women have learnt the skills of problem solving better than housekeeper women that this point can be resulted from their more presence in the society due to their employment and this can lead to face with more opportunities in the society and learn skills to use them in their life. In this research, the average dominant conflict resolution style in employed women was more than that of the housekeeper women and this is because of more competitive environment for women in the society due to their employment. Also, the average avoiding conflict resolution style in employed women is more than that of the housekeeper women. But there is no difference in the average reconciliation conflict resolution style between employed and housekeeper women, maybe because of their absence in home tasks, because when a woman is employed in the society it is expected since she works outside home, her husband help her in family environment and sometimes due to lack of husband cooperation, avoiding conflict resolution style can be taken place in women. The results showed that employed women self-controlling is more than that of the housekeeper women and this is due to excitement management and emotion management of employed women because of more presence in the society and facing with various opportunities and utilizing the others' experiences due to more communications with the others. The results showed that hyperactivity and aggression of girls with employed mothers are more than that of the girls with housekeeper mothers. Attention deficit disorder in girls with employed women is more than that of the girls with housekeeper women. This can be resulted from the fact that employed mothers due to their employment in the society, allocate less time for their family and children with respect to housekeeper mothers and this causes children may be more likely to interfere with attention deficit disorder. Sometimes, due to high pressure of work, employed women experience more stress and anxiety that this stress and anxiety are transferred into the home environment and finally children. Sometimes, employed mothers' impatience can result in less attention to children and finally their depression. Previously, research has shown that domineering methods are determined by threatening orientation. In accompaniment method, information exchange and investigating differences are to achieve an acceptable solution for both sides. This method is in relation with problem solving and it can result in creative problem solving (Sorenson, 1999). Also, studies have shown that required conflict resolution style or kind method indicates attempts for decreasing differences and emphasizes similarities for achieving expectations and the others' issues. The reconciliation method is located in middle point of attention to expectations and needs of others and refers to division of scores among both sides (Sorenson, 1999). The results of studies have shown that avoiding method is in relation with seclusion opportunities, giving responsibility to others, incriminating others, and receding own self (Sorenson, 1999). In families where the shapes of social behaviors are improper, inconsistent children are grown up. And even if these children can show consistency to some extent outside of the house and among their friends, they will probably have inconsistency in many social activities (Yavouzar, 2003). Finally, avoiding style is determined with properties such as evading, behaving passively or not acting, and dependence (Dezorila et al., 2011). In this field, studies have shown that training the skills of conflict resolution and communications to couples leads to mental health improvement (Askari et al., 2013). Improving their mental health is accompanied by better training of children and the latter is accompanied by less behavioral problems and disorders. Findings of the present study determine the necessity of preventive programs and therapeutic interventions for children in families with employed mothers. However, treatment of behavioral disorders is very important, but the necessity of preventive programs for preventing the occurrence

Volume 2

Page 6 
of behavioral disorders is more vital. Preventive programs can be focused in four aspects of training children, family, school, and society (planners and authorities). Undoubtedly, helping children with behavioral disorders is necessary because the continuation of behavioral disorders within life with the onset of childhood determine the importance of early intervention not only for decreasing suffering of children and adolescents but also for preventing a wide range of psychological problems in adulthood.

\section{REFERENCES}

[1] Babapour, Kheir Aldin, J. (2006), investigating the relationship between conflict resolution practices of communication and psychological health of students, Scientific-Research Journal of Psychology, University of Tabriz, 4, pp. 27-46.

[2] Beverly J. W. Holly P., Jenna Y., Kathleen K., Jessica B., Lindsey K.\& Diana C.(2014), Parental Emotion Coaching: Associations With Self-Regulation in Aggressive/Rejected and Low Aggressive/Popular Children, Child \& Family Behavior Therapy. Vol 36, Issue 2, p.p.: 81-106.

[3] Byrne BA, Haddock CK, \& Poston DC, (2002). Mid American Heart Institiute: Parenting style and adolescent smoking. Journal of Adolescent Health, (30)6, 418-425.

[4] Duman, S. \& Margolin, G. (2007). Parents' Aggressive Influences and Children's Aggressive Problem Solutions With Peers. Journal of Clinical Child and Adolescent Psychology, 36(1), 42-55

[5] Dustin A. Pardini, Rebecca Waller, Samuel W. Hawes(2015),Familial Influences on the Development of Serious Conduct Problems and Delinquency, The Development of Criminal and Antisocial Behavior,p.p. 201-220.

[6] Fanti, k.a. (2007), trajectories of pure and co-occurring internalizing and externalizing problems from age2to12: findings fromthenichd.study of the requirements for PhD degree. Georgiastste University.

[7] Farzadfar, Z., Homan, H., (2008), the role of the role of parenting skills on reducing maternal stress in mothers and behavioral problems in children, Journal of Iranian psychologists, 4 (15), pp. 277-292.

\section{[8]}

[9] Fortin, L;lessard, A;\&marcotte, D.(2010),Comparison by gender of students with behavior problems who dropped out of school. Journal of social and behavioral sciences. , 2.

\section{[10]}

[11] Goudarzi, Z., Bakhti, O., Yousefi, F., Shamshiri, A., Mahmoudi Gharaei, J., Atef Vahid, M., Voskouei Ashkouri, K., Abbasi Marei, F., Etaati, Z., (2010), investigating the relation shift work with abilities and behavioral problems in 7 to 12 year old-children of employed parents with shift work, Research and Nursing, 5 (18), pp. 42-50.

[12] Hallahan, de , Kauffman, J, (1944), Exceptional Children: An introduction to special education, translated by Mojtaba Javadian, (2008), Mashhad: Astan_e_Qods_e_Razavi Press.

[13] Khazaei, T., Khazaei, M.M., Khazaei, M., (2005), the prevalence of behavioral problems in Birjand children, Birjand University of Medical Science Journal, 12 (1\&2), pp.71-96.

[14] Kumru Asiye, Thompson, Ross A.(2003). "Ego Identity Status and Self Monitoring Behavior in Adolescents”, 
Journal of Adolescen t Research, Vol. 18 No.5, pp , 481-495.

[15] Lubenko, J; \& sebre, S (2010), Longitudinal associations between adolescent behavior problems and perceived family relationships. Journal of procedia social and behavior sciences.5.

[16] Mohammadzadeh, A., Najafi, M., (2010), the role of anxiety and depression in determining attention deficit disorders in high school children, Clinical Psychology Journal, 1 (4), pp. 59-66.

[17] Rahim, A, Kaufman, S \& Psennica, C. (2004). A Model of the style of Handling conflict, Marital satisfaction, and Instability. Available online at: http://papers.ssrn.com/sol3/ Data_ Integrity_ Notice.cfm?abid=602765

[18] Soltanifar, A., Bina, M., (2007), investigating the prevalence of depression symptoms in high school 9-11 year old-children in Shiraz (Iran) and its relation with family function, Journal of Mental Health Principles, 9 (33\&34), pp. 7-14.

[19] Stefan, C; \&Miclea, M.(2010), Prevention program for children with emotional and social competencies. Journal of prcedia social and behavioral sciences, 5, p.p.:127-139.

[20] Tate,Brian(2008). "A Longitudinal Study of the Relationships Among Self - Monitoring, Authentic Leadership, and Perception of Leadership . Journal of Leadership \& Organizational Studies. Vol15, n1, p.p.: 16-29.

Citation: Mehdi Akbarian, Zohreh Mazinani, Survey of Difference of Conflict Resolution Styles and Behavioral Problems of Girls In Employed Mothers with Housekeeper Mothers. American Research Journal of Humanities and Social Sciences, Volume 2, 2016; pp:1-8

Copyright (c) 2016 Mehdi Akbarian, Zohreh Mazinani. This is an open access article distributed under the Creative Commons Attribution License, which permits unrestricted use, distribution, and reproduction in any medium, provided the original work is properly cited. 